\title{
ANALISIS SWOT DALAM PENENTUAN STRATEGI PEMASARAN PRODUK PEMBIAYAAN PADA PT. PANIN BANK SYARIAH, TBK. KANTOR CABANG MALANG
}

\author{
Fani Firmansyah \\ Email : firmansyahfani@yahoo.co.id \\ Kotijah Fadilah Abdilah \\ Email : kotifa2015@gmail.com
}

\begin{abstract}
Abstrak : Tujuan dari penelitian ini PT Panin Bank Syariah, Tbk. (PBS) perlu menetapkan strategi-strategi yang tepat agar kehadirannya dapat memperoleh respon positif dari masyarakat dan produk serta jasa yang ditawarkan sesuai dengan kebutuhan dan keinginan masyarakat. Penelitian ini akan dilakukan di PT. Panin Bank Syariah, Tbk. Kantor Cabang Malang yang terletak di Jl Mgr Sugiopranoto No 7 kota Malang Provinsi Jawa Timur. Jenis penelitian ini adalah penelitian kualitatif dengan pendekatan deskriptif. Dari hasil matriks SWOT dapat diambil beberapa strategi yang sesuai dengan keadaan PT Panin Bank Syariah, Tbk. Kantor Cabang Malang bedasarkan beberapa hal yaitu : Segmentasi, Targeting, Positioning, Marketing Mix. Berdasarkan penelitian yang telah dilakukan oleh peneliti, maka kesimpulan dari hasil penelitian ini yaitu: (a) Strategi pemasaran khususnya pemasaran produk pembiayaan yangditerapkan oleh PT. Panin Bank Syariah, Tbk. Kantor Cabang Malang meliputi beberapa strategi, yakni strategi jemput bola, referal, membangun jaringan, memberikan servise excellent, dan memberikan fasilitas yang memuaskan untuk meningkatkan kepercayaan dan kepuasan nasabah, sehingga nasabah yang ada tidak akan lari dari bank. (b) Hasil analisis SWOT menyebutkan bahwa PT. Panin Bank Syariah, Tbk. Kantor Cabang Malang sudah bisa bersaing di pasar persaingan yang kompetitif yang ada di wilayah Malang.
\end{abstract}

Kata kunci : SWOT, Marketing Mix, Segmentasi, Targeting, Positioning

\section{PENDAHULUAN}

Dewasa ini istilah Bank Syariah sudah tidak asing lagi di telinga masyarakat Indonesia, hal ini juga dibuktikan dengan berdirinya institusi bank-

Fani Firmansyah, adalah Dosen Fakultas Ekonomi Universitas Islam Negeri Maulana Malik Ibrahim Malang

Kotijah Fadilah Abdilah, adalah Mahasiswa Fakultas Ekonomi Universitas Islam Negeri Maulana Malik Ibrahim Malang 
bank syariah yang semakin banyak tersebar diberbagai daerah. Dalam hal ini pemerintah juga turut mendukung dalam pengembangan bank syariah yang ditandai dengan lahirnya UU No 7 Tahun 1992 walaupun masih lemah landasan hukumnya. Oleh karena itu, pemerintah merevisinya hingga menjadi UU NO 10 Tahun 1998. Dalam UU tersebut tertulis bahwa bank konvensional diperbolehkan membuka unit yang berbasis syariah. Sejak saat itu mulailah bermunculan bank konvensional yang membuka unit-unit bank syariah.

Dimulai pada tahun 1992, fasilitas dan produk-produk perbankan bisa menjangkau secara luas kepada masyarakat yaitu bisa dinikmati oleh masyarakat petani, maupun para pedagang kecil melalui kredit usaha kecil, kredit perumahan rakyat, kredit perdagangan dengan berbagai kemudahan dan persyaratanpersyaratan yang lunak (Sinungan : 2000). Oleh sebab itu sektor-sektor industri baik kecil, menengah yang menggunakan modal tinggi bisa bertahan melalui kredit perbankan.

Bank Indonesia (2013) melaporkan bahwa bank syariah tumbuh dengan pesat antara 40-60\% pertahun. Menurut Bank Indonesia (2013) saat ini terdapat 11 Bank Umum Syariah (BUS), 24 Unit Usaha Syariah (UUS), dan 158 Bank Pekreditan Rakyat Syariah (BPRS). Dengan diberlakukannya Pasar Bebas ASEAN pada tahun 2015, Bank Syariah di Indonesia memiliki peluang sekaligus tantangan dalam mengembangkan dan meningkatkan kontribusi bank syariah tehadap industri perbankan di Indonesia. Untuk itu tentunya diperlukan strategi yang tepat dan efektif untuk dapat menguwujudkan bank syariah yang sehat dan kuat secara finansial dan senantiasa patuh kepada prinsip-prinsip syariah.

Pada tahun 2009 PT Panin Bank Syariah, Tbk. (PBS) berdiri, yang merupakan Bank Umum Syariah sejak awal dibentuk bukan dari unit syariah bank konvensional. Walaupun dibilang belum lama beroprasi di bandingkan bank-bank umum syariah lainnya akan tetapi PBS membuktikan kualitas dan eksistensinya dibidang ini dengan menempatkan sektor perbankan Syariah ke jenjang yang baru melalui debutnya sebagai bank Syariah pertama di Indonesia yang terdaftar di Bursa Efek Indonesia (go public), sejak awal tahun ini. Saham PBS secara resmi mulai diperdagangkan di Bursa Efek Indonesia pada, 15 Januari 2014. Total 4,75 miliar saham atau total $48,72 \%$ dari modal disetor, dan 950 juta lembar warrant diterbitkan, memberikan kesempatan kepada para investor dalam maupun luar negeri untuk terlibat dalam salah satu segmen perbankan Indonesia yang paling cepat berkembang. Dana yang diperoleh dari Penawaran Saham Perdana (IPO) akan dipergunakan untuk mendukung struktur permodalan, ekspansi pembiayaan, dan perluasan jaringan dari PBS. Operasional PBS diharapkan menjangkau jutaan penduduk Indonesia yang masih di luar sistem perbankan konvensional. Aries Muftie, Presiden Komisaris PBS mengatakan bahwa sejatinya perbankan syariah merupakan solusi finansial bagi penduduk Indonesia yang berpenghasilan menengah ke bawah yang belum terjangkau oleh bank-bank konvensional.

Bank Syariah yang pada dasarnya bertujuan untuk meningkatkan kesejahteran masyarakat sehingga dengan produk pembiayaan dari PBS yang ditawarkan. Akan tetapi mengingat kegiatan pemasaran dilaksanakan mulai pada perencanaan, penentuan produk, harga, distribusinya dengan maksud memuaskan kepentingan dan sesuai dengan kebutuhan konsumen atau nasabah. Dalam 
kegiatan pemasaran diperlukan juga konsep strategi, sehingga jasa dan produk yang ditawarkan dapat segera digunakan oleh nasabah. Strategi yang tepat dan disesuaikan dengan kebutuhan dan kemampuan masyarakat sebagai sasaran. Karena kegiatan tersebut tidak mudah, mengingat persaingan yang dihadapi di pasar sangat ketat, sehingga perbankan syariah dituntut untuk bergerak cepat dengan menetapkan strategi yang sesuai dengan kekuatan, kelemahan, peluang dan ancaman untuk bisa tetap bertahan hidup di tengah dunia persaingan yang semakin ketat.

Menurut data dari PT. Panin Bank Syariah, Tbk. Cabang Malang untuk tahun 2011 dana yang disalurkan untuk pembiayaan sebesar 31,354 Miliar, untuk tahun 2012 dana yang disalurkan untuk pembiayaan sebesar 19,8 Miliar, dan untuk tahun 2013 dana yang disalurkan untuk pembiayaan sebesar 4,760 Miliar. Data di atas adalah data pembiayaan new (cair) pada tahun tersebut. Dari data pembiayaan tersebut dapat dilihat bahwa dari tahun ketahun dana pembiayaan semakin menurun, sehingga dalam kondisi persaingan yang sangat ketat PT Panin Bank Syariah, Tbk. (PBS) perlu menetapkan strategi-strategi yang tepat agar kehadirannya dapat memperoleh respon positif dari masyarakat dan produk serta jasa yang ditawarkan sesuai dengan kebutuhan dan keinginan masyarakat, sehingga dana yang disalurkan untuk produk pembiayaan dapat meningkat dan produk pembiayaan dapat bersaing dengan bank-bank yang lain baik Bank Syariah maupun Bank Konvensional yang ada di wilayah Kota Malang dan sekitarnya.

Oleh sebab itu dari data yang diperoleh dari PT. Panin Bank Syariah, Tbk. Kantor Cabang Malang untuk produk pembiayaan yang terus menurun dari setiap tahunnya. Diperlukan strategi pemasaran yang efisien dan efektif untuk meningkatkan keuntungan dari produk pembiayaan tersebut. Akan tetapi usaha tersebut tidak mudah dikarenakan perusahaan harus memiliki strategi bersaing yang tepat dalam usahanya mencapai target yang diharapkan. Situasi perkembangan kondisi global yang semakin tak menentu dan berubah-ubah setiap waktunya. Hal tersebut dapat menjadikan peluang peningkatan keuntungan atau bahkan menjadi ancaman bagi bank. Salah satu upaya untuk mengetahui strategi yang tepat bagi bank adalah dengan analisis SWOT. Analisis SWOT yang terdiri dari faktor internal dan faktor eksternal. Faktor internal ini merupakan faktor yang berasal dari internal PT. Panin Bank Syariah, Tbk. Kantor Cabang Malang, yang meliputi faktor kekuatan (Strenght) dan kelemahan (Weakness) yang dimiliki oleh PT Panin Bank Syariah, Tbk. (PBS). Sedang faktor eksternal terdiri dari dua komponen, yakni faktor peluang (Opportunities) dan ancaman (Threath) yang dihadapi oleh PT Panin Bank Syariah, Tbk. (PBS) untuk mengetahui problematika yang terjadi dan mendapatkan solusi untuk meningkatkan profit dari produk pembiayaan yang ada pada PT. Panin Bank Syariah, Tbk. Kantor Cabang Malang. Dengan demikian, perusahaan mampu bersaing dan mencapai tujuan secara efektif dan efisien.

Menurut Lamb, dkk (2001) dalam Nuariputri (2010) menjelaskan bahwa strategi pemasaran adalah suatu kegiatan menyeleksi dan penjelasan suatu atau beberapa target pasar dan mengembangkan serta memelihara suatu bauran pemasaran yang akan menghasilkan kepuasan konsumen dengan pasar yang dituju. dimana Dalam menentukan strategi pemasaran yang sesuai dengan keadaan pasar dan perusahan maka perlu melakukan beberapa langkah menurut Kasmir (2004) 
ada tiga tahapan yaitu Segmentation (Segmentasi Pasar), Targeting (Penentuan Posisi Pasar), Positioning (Strategi Memasuki Pasar) serta marketing mix (bauran pemasaran). Di dalam bauran pemasaran terdapat ada 4P yang utama yaitu Product, Price, Place dan Promotion, akan tetapi lebih sempurna lagi bila ditambah dengan 3P dalam bauran pemasaran yaitu People, Process, dan Physical Evidence

PT Panin Bank Syariah, Tbk. (PBS), produk pembiayaan yang ditawarkan yaitu pembiayaan murabahah, mudharabah dan musyarakah. Dari banyak produk dan varian produk yang di tawarkan, kenapa dana yang tersalurkan untuk pembiayaan setiap tahun terus berkurang. Dari penjelasan yang telah dikemukakan, muncul ketertarikan untuk meneliti dan mengambil topik mengenai "Analisis SWOT Dalam Penentuan Strategi Pemasaran Produk Pembiayaan Pada PT. Panin Bank Syariah, Tbk. Kantor Cabang Malang ".

\section{METODE}

Penelitian ini akan dilakukan di PT. Panin Bank Syariah, Tbk. Kantor Cabang Malang yang terletak di Jl Mgr Sugiopranoto No 7 kota Malang Provinsi Jawa Timur. Jenis penelitian ini adalah penelitian kualitatif dengan pendekatan deskriptif. Menurut Moleong (2005) penelitian kualitatif sebagai prosedur penelitian yang menghasilkan data deskriptif berupa kata-kata tertulis atau lisan dari orang-orang dan perilaku yang dapat diamati.

Maka dengan ini dituntut keterlibatan peneliti secara aktif dalam pengumpulan data penelitian. Yang dimaksudkan mengetahui informasi terkait pembiyaan yang diberikan kepada nasabah baik kekuatanya, kelemahannya, ancaman serta peluang yang dihadapi bank pada produk pembiayaan berdasarkan yang ada di PT. Panin Bank Syariah, Tbk. Kantor Cabang Malang.

Data primer yang digunakan oleh peneliti adalah berupa data rincian tentang jumlah pembiayaan yang diberikan kepada nasabah di PT. Panin Bank Syariah, Tbk. Kantor Cabang Malang. Didukung dengan data sekunder yang diperoleh dari berbai sumber seperti buku, laporan, jurnal, dan lain-lain. Data yang diperoleh berupa jurnal-jurnal tentang penelitian yang terkait dengan judul peneliti dan informasi lain yang dibutuhkan tentang analisis SWOT sebagai dasar penentuan strategi pemasaran.

Teknik pengumpulan data yang digunakan dalam penelitian ini adalah teknik pengamatan (observasi), wawancara, studi kepustakaan. Pada penelitian ini, penulis menggunakan metode analisis data berupa studi deskriptif, yaitu dengan mengimplementasikan semua data yang diperoleh berupa gambaran, alasan, dan penjabaran keadaan yang sebenarnya sesuai dengan data-data dari perusahaan, kemudian melakukan pengumpulan serta penafsiran yang disesuaikan dengan teori untuk ditarik suatu kesimpulan yaitu penerapan strategi pemasaran produk pembiayaan yang tepat pada PT. Panin Bank Syariah, Tbk. Cabang Malang.

Untuk menganalisis posisi perusahaan dalam persaingan yang sangat ketat, metode analisis yang digunakan adalah analisis SWOT yang membandingkan antara faktor ekstern, yaitu peluang, ancaman dan faktor internal yaitu kekuatan, kelemahan (Rangkuti, 2005). 
Penggunaan anlisis SWOT dimaksudkan untuk memperjelas semua kekuatan dan kelemahan yang dapat diidentifikasi guna memberikan suatu rekomendasi pengembangan berdasarkan potensi-potensi yang tersedia di dalam lingkungan internal perusahaan, dan menganalisa peluang serta ancaman yang berasal lingkungan eksternal perusahaan. Dimana ujuan utama pengamatan lingkungan eksternal adalah untuk melihat peluang baru untuk perusahaan dapat beroperasi secara menguntungkan. Ancaman lingkungan eksternal adalah tantangan akibat kecenderungan atau perkembangan yang kurang menguntungkan yang akan mengurangi penjualan dan laba.

Alat untuk menyusun faktor-faktor strategis perusahaan diatas adalah Matriks SWOT. Matrik ini menggambarkan secara jelas bagaimana peluang dan ancaman yang dihadapi perusahaan dapat disesuaikan dengan kekuatan serta kelemahan yang dihadapi oleh perusahaan guna mencapai tujuan yang diharapkan ( Rangkuti : 2001) dalam Choirunnisak.

Tabel 1

Matrik SWOT

\begin{tabular}{|l|l|l|}
\hline \multicolumn{1}{|c|}{ IFAS } & $\begin{array}{l}\text { Strenght } \text { (S) } \\
\text { Tentukan 5-10 faktor- } \\
\text { faktor kekuatan } \\
\text { internal }\end{array}$ & $\begin{array}{l}\text { Weaknesess }(\mathrm{W}) \\
\text { Tentukan 5-10 faktor- } \\
\text { faktor kelemahan } \\
\text { internal }\end{array}$ \\
\hline $\begin{array}{l}\text { Opportunies (O) } \\
\text { Tentukan 5-10 faktor } \\
\text { peluang eksternal . }\end{array}$ & $\begin{array}{l}\text { Strategi SO } \\
\text { Menciptakan strategi } \\
\text { yang menggunakan } \\
\text { kekuatan untuk } \\
\text { memanfaatkan } \\
\text { peluang. }\end{array}$ & $\begin{array}{l}\text { Strategi WO } \\
\text { Menciptakan strategi } \\
\text { yang meminimalkan } \\
\text { untuk memanfaatkan } \\
\text { peluang. }\end{array}$ \\
\hline $\begin{array}{l}\text { Threaths (T) } \\
\text { Tentukan 5-10 faktor } \\
\text { ancaman eksternal }\end{array}$ & $\begin{array}{l}\text { Strategi ST } \\
\text { Menciptakan strategi } \\
\text { yang menggunakan }\end{array}$ & $\begin{array}{l}\text { Strategi WT } \\
\text { Menciptakan strategi } \\
\text { yang meminimalkan } \\
\text { kelemahan dan } \\
\text { menghindari ancaman. }\end{array}$ \\
\hline
\end{tabular}

Sumber : Rangkuti 2000 dalam Choirunnisak.

Setelah menganalisa melalui Matrik SWOT maka akan memperoleh empat alternatif bagi perusahaan untuk melakukan strategi pemasaran produk pembiayaan yang ada di PT. Panin Bank Syariah, Tbk. Kantor Cabang Malang. Alternatif-alternatif strategi pemasaran tersebut antara lain :

a. Strategi SO (Strength-Opportunity)

b. Strategi WO (Weakness-Opportunity)

c. Strategi ST (Strength-Threat)

d. Strategi WT (Weakness-Threat)

Interpretasi Hasil Analisis SWOT untuk Pengembangan :

a. Jika faktor kekuatan dan peluang lebih dominan atau lebih besar dari kelemahan dan ancaman maka perbaikan melakukan ekspansi atau perbankan sudah berani bersaing dengan pesaing-pesaing yang ada. 
b. Jika faktor kekuatan dan peluang lebih kecil bila dibandingkan dengan faktor kelemahan dan ancaman maka perbankan harus melakukan konsolidasi kedalam untuk memperkuat dirinya sebelum bersaing dengan yang lain.(Choirunnisak:2012)

\section{PEMBAHASAN}

\section{SWOT PT. Panin Bank Syariah, Tbk. Kantor Cabang Malang}

Pengembangan strategi pemasaran produk pembiayaan PT. Panin Bank Syariah, Tbk. Kantor Cabang Malang dilakukan dengan anlisis SWOT. SWOT dari PT. Panin Bank Syariah, Tbk. Kantor Cabang Malang adalah :

a. Strenght (kekuatan)

PT. Panin Bank Syariah, Tbk. Kantor Cabang Malang mempunyai beberapa kekuatan yang mendukung dalam memasarkan produk-produknya. Kekuatan tersebut adalah sebagai berikut:

1) Go Public

PT. Panin Bank Syariah, Tbk. adalah Bank Syariah pertama dan satusatunya Bank Syariah di Indonesia yang terdaftar di Bursa Efek Indonesia (go public) untuk saat ini.Saham PBS secara resmi mulai diperdagangkan di Bursa Efek Indonesia pada, 15 Januari 2014. Total 4,75 miliar saham atau total 48,72\% dari modal disetor, dan 950 juta lembar warrant diterbitkan. Ini menjadi kekuatan bagi bank karena dengan terdaftarnya PT. Panin Bank Syariah, Tbk. maka akan mempermudah kepada para investor dalam maupun luar negeri untuk terlibat dalam salah satu segmen perbankan Indonesia yang paling cepat berkembang. Dana yang diperoleh dari Penawaran Saham Perdana (IPO) akan dipergunakan untuk mendukung struktur permodalan, ekspansi pembiayaan, dan perluasan jaringan dari PT. Panin Bank Syariah, Tbk.

2) Fleksibel

Produk pembiayaan yang ditawarkan oleh PT. Panin Bank Syariah, Tbk. telah disesuaikan dengan keinginan dan kebutuhan para nasabahnya dan bisa berubah sesuai dengan kondisi serta kebutuhan nasabah. Misalnya Pembiayaan Multi Jasa (PMJ) dengan keunggulan seperti Membiayai kebutuhan serbaguna yang bersifat jasa/manfaat, dan Untuk kebutuhan jasa/manfaat jangka waktunya flexible

3) Dukungan Pemerintah, ulama, dan komunitas-komunitas

Tanpa adanya pihak-pihak tersebut, PT. Panin Bank Syariah, Tbk. tidak akan bisa berdiri di Malang. Peran pemerintah penting dalam perkembangan lembaga keuangan syariah. Misalnya saja, peran pemerintah dalam berdirinya bank syariah adalah dengan dikeluarkannya UU No. 10 tahun 1998 yang menerangkan boleh beroprasinya bank syariah. Peran ulama juga demikian, masyarakat Indonesia mayoritas mempunyai kultur yang sama yakni tunduk kepada perkataan Ulama. Sehingga bank dalam memasarkan produk hendaknya melibatkan tokoh ulama setempat. Begitu juga peran komunitaskomunitas, komunitas sebagai sekumpulan dari orang-orang yang bersatu dalam satu kegiatan dan satu tempat, berpotensi dalam menyalurkan produk- 
produk bank karena cukup dengan mendatangi satu tempat maka terdapat banyak calon nasabah. Contohnya koperasi bank hanya mendatangi satu koperasi tetapi bank memiliki banyak calon nasabah untuk memasarkan produknya karena didalam kopeasi memiliki banyak anggota. Dan untuk saat ini memang bank koperasi di Malang yang sudah menjadi nasabah bank ini.

\section{4) Jaringan Kerja}

Saat ini PT. Panin Bank Syariah, Tbk. sudah mempunyai jaringan kerja dengan lembaga-lembaga perbankan konvensional maupun syariah di Indonesia. Dalam hal ini nasabah bisa melakukan transaksi, penarikan tunai, di ATM perbankan yang tergabung dalam ATM bersama. Langkah ini merupakan kekuatan yang bisa dimanfaatkan untuk menggait nasabah sebanyak mungkin. Karena dengan kemudahan bertransaksi seperti ini, dimungkinkan banyak nasabah yang tertarik dalam menggunakan jasa PT. Panin Bank Syariah, Tbk.

\section{5) Tempat Strategis}

Untuk saat ini lokasi kantor PT. Panin Bank Syariah, Tbk. Cabang Malang berada pada pusat kota malang yaitu terletak di Jalan Mgr Sugiapranoto No 7 Kota Malang, dan lokasi kantor tidak jauh dari Alun-alun Kota, kantor Bank Indonesia, Kantor Pajak, dan Balai kota karena tempat-tempat tersebut dapat dijangkau dengan jalan kaki dan tidak memerlukan waktu lama.

\section{b. Weakness (kelemahan)}

PT. Panin Bank Syariah, Tbk. Kantor Cabang Malang mempunyai beberapa kelemahan dalam memasarkan produk-produknya. Kelemahan tersebut adalah sebagai berikut:

1) Kurangnya sosialisasi ke masyarakat

Dalam kurun waktu ini, keberadaan PT. Panin Bank Syariah, Tbk. Kantor Cabang Malang belum banyak diketahui oleh sebagian besar masyarakat Malang. Mungkin bisa dimaklumi, karena berdirinya PT. Panin Bank Syariah, Tbk. Kantor Cabang Malang bisa dikatakan masih muda dan berdirinya PT. Panin Bank Syariah, Tbk. Kantor Cabang Malang ini hasil dari akuisisi Bank Harfa yang ada pada saat itu jadi banyak masyarakat sekitar yang beranggapan bahwa PT. Panin Bank Syariah, Tbk. Kantor Cabang Malang adalah Bank Harfa yang kondisinya saat itu adalah bank konvensional. Hanya saja kondisi demikian jika tidak di manajemen dengan baik, akan mengancam eksistensi PT. Panin Bank Syariah, Tbk. Kantor Cabang Malang.

\section{2) Produk yang belum dikenal}

Secara umum, produk perbankan syariah memang belum banyak dikenal oleh masyarakat. Mereka masih sangat awam dengan istilah-istilah yang digunakan di lembaga perbankan syariah. Oleh karena itu hal ini merupakan salah satu kelemahan yang membutuhkan strategi jitu dalam mengenal produk bank syariah kemasyarakat terutama masyarakat umum yang tidak terlalu mendalamiagama islam. 
3) Tempat Kurang Menarik

Karena PT. Panin Bank Syariah, Tbk. Kantor Cabang Malang adalah bank hasil dari akuisisi Bank Harfa maka tempatnya juga masih milik Bank Harfa yang dibangun sejak awal Bank Harfa, dan belum ada renovasi cuma pengecetan ulang. Sehingga bila dilihat dari luar tempat PT. Panin Bank Syariah, Tbk. Kantor Cabang Malang seperti gedung tua yang tidak lagi digunakan. Sehingga para calon nasabah yang akan datang ketempat ini menjadi ragu-ragu akan kualitas PT. Panin Bank Syariah, Tbk. Kantor Cabang Malang. Hal ini menjadi sangat penting karena ini merupakan kesan pertama yang akan diperoleh oleh nasabah dan biasanya kesan pertama itu merupakan hal yang paling berpengaruh.

4) Fasilitas Kantor Kurang Memadai

Pada saat ini PT. Panin Bank Syariah, Tbk. Kantor Cabang Malang hanya memiliki dua mobil dinas sehingga bila ada keperluan dengan para nasabah untuk pemasaran maka para marketing harus gentian kadang memakai mobil pribadi. Sehingga jika ada keperluan mendesak sering kebingungan, jika hal ini terus berkelanjutan di khawatirkan akan membuat nasabah kecewa karena pelayanan kurang memeuaskan.

5) Proses Pencairan Dana Pembiayaan Lama

Dalam proses pengajuan pembiayaan pastilah ada anggunannya, dan di PT. Panin Bank Syariah, Tbk. Kantor Cabang Malang masih belum ada tim yang fungsinya untuk pengecekan dan menilai anggunan tersebut, sehingga masih menggunakan tim dari kantor cabang yang ada di Surabaya dan hal itu memeakan waktu yang lama karena harus disesuaikan dengan kondisi cabang Surabaya.

c. Opportunities (peluang)

PT. Panin Bank Syariah, Tbk. Kantor Cabang Malang mempunyai beberapa peluang yang berasal dari lingkungan eksternal bank. Peluang tersebut adalah sebagai berikut:

1) Kerjasama dengan instansi dan koperasi

Selama ini koperasi jarang sekali bersentuhan dengan perbankan. Padahal usaha koperasi membutuhkan relasi seperti bank dalam memperoleh pembiayaan. Dengan memberikan syarat yang lebih mudah jika dibandingkan dengan bank konvensional, sehingga sebagian besar koperasi yang ada di mlang sudah menjadi nasabahPT. Panin Bank Syariah, Tbk. Kantor Cabang Malang.

2) Pangsa Pasar

Pangsa pasar dari PT. Panin Bank Syariah, Tbk. Kantor Cabang Malang untuk saat ini adalah koperasi yang memang pangsa pasar yang blom dilirik oleh bank konvensional maupun bank syariah. Terbukti untuk wilayah kota Malang Bank yang fokus pada pangsa pasar koperasi hanya BTN, Muamalat dan Niaga. Sehingga ini merupakan peluang besar bagi PT. Panin Bank 
Syariah, Tbk. Kantor Cabang Malang untuk lebih mengoptimalkan pangsa pasar ini.

3) Lembaga Keuangan Syariah yang semakin banyak

Jumlah lembaga keuangan syariah di Indonesia tumbuh dengan sangat pesat Bank Indonesia (2013) melaporkan bahwa bank syariah tumbuh antara 40-60\% pertahun. Menurut Bank Indonesia (2013) saat ini terdapat 11 Bank Umum Syariah (BUS), 24 UnitUsaha Syariah (UUS), dan 158 Bank Pekreditan Rakyat Syariah (BPRS). Hal ini menjadi salah satu peluang bagi PT. Panin Bank Syariah, Tbk. karena dengan semakin meningkatnya jumlah lembaga keuangan syariah berati meningkat pula peminat dari lembaga keuangan syariah. Selanjutnya tinggal bagaimana PT. Panin Bank Syariah, Tbk. dengan strateginya memanfaatkan peluang ini sehingga dapat menguntungkan bagi bank.

4) Kota Pendidikan

Kota malang disebut juga kota pelajar setelah kota surabaya untuk wilayah jawa timur, banyak mahasiswa yang berasal dari luar kota malang bahkan luar pulau jawa datang ke malang untuk belajar. Hal ini terbukti dari 5 Perguruan Tinggi Negeri terdapat 260.118 mahasiswa, dan dari 48 Perguruan Tinggi Swasta terdapat 387.769 mahasiswa. Hal ini memberikan peluang bagi PT. Panin Bank Syariah, Tbk. Kantor Cabang Malang untuk mengembangkan produknya lebih inovatif untuk ditunjukan kepada para pelajar. Karena para pelajar tidak mau direpotkan oleh hal-hal yang berhubungan dengan uang mereka lebih berfokus pada belajar. Mereka biasanya lebih memilih bank yang menawarkan fasilitas, keuntungan yang lebih banyak akan tetapi tidak merepotkan meraka dalm menggunakan jasa perbankan ini.

5) Mayoritas penduduknya muslim

Walaupun kota malang adalah kota para pelajar dan para pendatang begitu banyak tetap saja malang manyoritas penduduknya adalah muslim. Dari data sp2010.bps.go.id menyatakan jumlah penduduk Malang berjumlah 2.416.110 dan yang beragama Islam 2.346.252. Hal ini menguntungkan bagi PT. Panin Bank Syariah, Tbk. Kantor Cabang Malang, karena masyarakat saat ini sudah mulai sadar bahwa bank konvensional menggunakan bunga yang berari riba dan itu ternasuk diharamkan oleh agama. Sehingga saat ini banyak masyarakat muslim yang sudah pindah dari bank konvensional ke bank syariah, sehingga PT. Panin Bank Syariah, Tbk. Kantor Cabang Malang harus memanfaatkannya dengan baik.

\section{d. Threat (ancaman)}

Ancaman disini meliputi faktor internal dan eksternal. Faktor internal yang bisa menjadi ancaman adalah ketidakmampuan lembaga dalam memanfaatkan kekuatan dan peluang yang ada. Sehingga yang terjadi kekuatan dan peluang tersebut bisa berubah menjadi ancaman besar dari lembaga (chorunnisak:2012). Sedangkan faktor eksternal yang menjadi ancaman dari PT. Panin Bank Syariah, Tbk. Kantor Cabang Malang:

1) Bank Syariah Lain

Ada banyak Bank syariah di Indonesia yang talah membuka cabangya dikota malang,karena kota malang dianggap kota yang mempunyai potensi 
tinggi untuk memasarkan produk-produk mereka. Terbukti ada enam Bank Umum Syariah dan Unit Usaha Syariah yang mempunyai cabang di kota malang, dan kantor mereka lebih dari satu hanya PT. Panin Bank Syariah, Tbk. Kantor Cabang Malang saja yang hanya memiliki satu kantor.Hal ini bisa jadiancaman besar bagi PT. Panin Bank Syariah, Tbk. Kantor Cabang Malang karena persaingan pasar akan semakin sengit dan kompetitif. Oleh karena itu sebelum hal tersebut terjadi, maka PT. Panin Bank Syariah, Tbk. Kantor Cabang Malang harus terus melakukan antisipasi dan evaluasi serta menetapkan strategi pemasaran yang tepat agar keberadaanya mendapat posisi di hati masyarakat. Oleh karena itu diperlukan strategi-strategi khusus dalam sosialisasi dan pemasarannya.

\section{2) Ekonomi ASEAN 2015}

Karena sebentar lagi akan berlaku Ekonomi ASEAN yang bebas maka PT. Panin Bank Syariah, Tbk. Kantor Cabang Malang harus mempunyai strategi pemasaran yang tepat agar tidak ketinggalan dengan bank-bank lain karena pesaingnya tidak hanya dari dalam negeri saja. Hal ini menyebabkan pertumbuhan perbankan syariah akan melambat. Kinerja perbankan syariah di dalam negeri juga masih dibayangi ketidakpastian ekonomi global. Hal ini karena non performing financing (NPF) pada tahun ini yang bisa lebih besar. Pasalnya, kredit macet perbankan syariah saat ini (6/3/2014) sudah mencapai 3 persen dan angka itu melebihi angka nasional kredit macet perbankan syariah hal ini Merujuk data statistik perbankan yang dihimpun OJK, tingkat NPF bank syariah per November 2013 mencapai 2,96 persen.

3) Sebagian masyarakat yang tidak tahu

Pada saat ini masih belum banyak orang yang percaya $100 \%$ bahwa bagi hasil (profit sharing) berbeda dengan bunga yang ada di bank umum konvensional. Dan ini juga dimanfaatkan oleh sebagian orang yang tidak menyukai berkembangnya bank syariah untuk membuat isu bahwa bagi hasil sebenarnya sama dengan bunga.

Strategi Pemasaran Produk Pembiayaan di PT. Panin Bank Syariah, Tbk. Kantor Cabang Malang Berdasarkan Analisis SWOT

Selanjutnya untuk mengetahui langkah-langkah yang perlu dilakukan PT. Panin Bank Syariah, Tbk. Kantor Cabang Malang dalam menentukan kebijakan strategi pemasaran untuk produk pembiayaan maka diperlukan matrik SWOT yang bisa menunjukkan faktor kekuatan, kelemahan, peluang dan ancaman yang dimiliki lembaga perbankan. Sehingga kemungkinan salah dalam mengambil keputusan dalam pemasaran bisa dihindari.

Berdasarkan matrik SWOT Rangkuti (2000), maka diperoleh hasil analisis SWOT PT. Panin Bank Syariah, Tbk. Kantor Cabang Malang dalam memasarkan produk pembiayaan adalah sebagai berikut: 
Tabel 2

Matrik SWOT

PT. Panin Bank Syariah, Tbk. Kantor Cabang Malang

\begin{tabular}{|c|c|c|}
\hline Eksternal & $\begin{array}{l}\quad \text { Strenghts (S) } \\
\\
\text { 1. Go Public } \\
\text { 2. Fleksibel } \\
\text { 3. Dukungan } \\
\text { pemerintah,ulama } \\
\text { dan komunitas } \\
\text { 4. Jaringan kerja. } \\
\text { 5. Tempat strategis }\end{array}$ & $\begin{array}{l}\text { Weakness (W) } \\
\text { 1. Kurang sosialisasi } \\
\text { 2. Tempat kurang } \\
\text { menarik } \\
\text { 3. Produk belumbanyak } \\
\text { dikenal. } \\
\text { 4. Fasilitas kantor } \\
\text { kurang memadai } \\
\text { 5. Proses pencairan dana } \\
\text { Pembiayaan yang } \\
\text { lama }\end{array}$ \\
\hline $\begin{array}{l}\text { Opportunities }(\mathrm{O}) \\
\\
\text { 1. Pangsa pasar } \\
\text { 2. Musim Bank Syariah } \\
\text { 3. Kerjasama dengan } \\
\text { instansi dan koperasi } \\
\text { 4. Mayoritaspenduduk } \\
\text { muslim } \\
\text { 5. Kota Pelajar }\end{array}$ & \begin{tabular}{ll} 
& \multicolumn{1}{|c}{ Strategi SO } \\
1. & Memperluas pangsa \\
pasar \\
2. \\
Memperkuat \\
kerjasama dengan \\
koperasi \\
3. Meningkatkan \\
hubungan dengan \\
ulama, pemerintah \\
dan komunitas \\
4. Menjalin kerjasama \\
dengan lembaga \\
pendidikan
\end{tabular} & $\begin{array}{l}\text { Strategi WO } \\
\text { 1. Strategi jemput bola } \\
\text { 2. Meningkatkan } \\
\text { loyalitas nasabah } \\
\text { 3. Peningkatan kualitas } \\
\text { produk }\end{array}$ \\
\hline $\begin{array}{l}\text { 1. Ketidakmampuan bank } \\
\text { dalam memanfaatkan } \mathrm{S} \\
\text { dan O } \\
\text { 2. Bank Syariah lain } \\
\text { 3. Ekonomi ASEAN } 2015 \\
\text { 4. Tahun Politik } \\
\text { 5. Sebagian masyarakat } \\
\text { yang iri dan tidak tahu }\end{array}$ & $\begin{array}{l}\text { Strategi ST } \\
\text { 1. Membuat produk } \\
\text { yang inovatif } \\
\text { 2. Menetapkan target } \\
\text { pemasaran } \\
\text { 3. Meningkatkan } \\
\text { kualitas pelayanan. }\end{array}$ & $\begin{array}{l}\text { Strategi WT } \\
\text { 1. Peningkatan promosi } \\
\text { dalam melalui berbagai } \\
\text { media. } \\
\text { 2. } \begin{array}{l}\text { Menetapkan strategi } \\
\text { pemasaran yang efektif } \\
\text { dan efisien. }\end{array}\end{array}$ \\
\hline
\end{tabular}

Sumber : Data yang diolah

Dilihat dari matrik SWOT diatas bisa dilihat bahwa faktor kekuatan lebih besar dibandingkan dengan faktor kelemahan yang dimiliki oleh bank dan faktor peluang juga lebih besar bila dibandingkan dengan faktor ancaman. Oleh sebab itu, dengan kondisi seperti itu PT. Panin Bank Syariah, Tbk. Kantor Cabang Malang 
seharusnya sudah cukup mampu untuk bersaing dengan lembaga-lembaga keuangan lain yang ada di Malang khususnya dengan lembaga keuangan syariah yang sudah lebih dulu ada. Berikut ini merupakan pengembangan strategi pemasaran dari hasil interpretasi analisis SWOT PT. Panin Bank Syariah, Tbk. Kantor Cabang Malang yakni:

1. Strategi SO (Strenghts opportunities)

Strategi yang berdasarkan pada kekuatan dan peluang yang dimiliki oleh PT. Panin Bank Syariah, Tbk. Kantor Cabang Malang, yaitu sebagai berikut:

a. Memperluas pangsa pasar

Strategi ini bersal dari penggabungan kekuatan PT. Panin Bank Syariah, Tbk yang sudah Go Public dengan peluang yang dimiliki olehPT. Panin Bank Syariah, Tbk. Kantor Cabang Malang yaitu pangsa pasar yang masih luas. Untuk memperluas pangsa pasar yang telah ada, PT. Panin Bank Syariah, Tbk. Kantor Cabang Malang tentunya harus melalui proses perencanaan yang matang. Agar pasar yang dimasuki tidak terjadi salah sasaran. Selain itu perluasan pangsa pasar ini juga harus melihat kemampuan yang dimiliki oleh PT. Panin Bank Syariah, Tbk. Kantor Cabang Malang. PT. Panin Bank Syariah, Tbk. Kantor Cabang Malang bisa melihat pasar yang ada di kota maupun kabupaten Malang, atau juga PT. Panin Bank Syariah, Tbk. Kantor Cabang Malang lebih melebarkan sayapnya di kota di luar Malang seperti Blitar dan Pasuruan dan kota-kota lain yang masih berpotensial. Karena pada saat ini pangsa pasar yang masih dominan untuk produk pembiayaan adalah koperasi saja.

\section{b. Memperkuat kerjasama dengan koperasi}

Strategi ini bersal dari penggabungan kekuatan PT. Panin Bank Syariah, Tbk yang memiliki jaringan kerja dan peluang manyoritas penduduk muslim. Jalinan kerjasama yang selama ini sudah terbangun dengan koperasi perlu dipertahankan. Karena melihat peluang besar yang bisa dimanfaatkan oleh PT. Panin Bank Syariah, Tbk. Kantor Cabang Malang dengan lembaga koperasi. Bank perlu memelihara rasa kepercayaan koperasi yang telah menjadi partner, agar koperasi tersebut tetap menjadi nasabah bank. Karena untuk wilayah kota Malang Bank yang fokus pada pangsa pasar koperasi hanya BTN, Muamalat dan Niaga.

c. Meningkatkan hubungan dengan ulama, pemerintah, dan komunitas

Strategi ini bersal dari penggabungan kekuatan PT. Panin Bank Syariah, Tbk yang memiliki dukungan dari tiga pihak dan memiliki peluang musim bank syariah. Ketiga pihak tersebut sangat berpengaruh terhadap kemajuan PT. Panin Bank Syariah, Tbk. Kantor Cabang Malang. Peran ulama yang selama ini kurang dioptimalkan oleh bank syariah maka PT. Panin Bank Syariah, Tbk. Kantor Cabang Malang harus mampu meningkatkan hubungan yang harmonis dengan tokoh-tokoh agama (ulama) yang ada. Karena para ulama ini kebanyakan dianut oleh masyarakat. Sehingga sangat efektif jika sosialisasi dan pemahaman adanya bank syariah di Malang melalui ahli-ahli agama yang ada. Selain itu peran pemerintah juga sangat berdampak positif bagi kemajuan bank syariah. Secara nasional pemerintah telah mengeluarkan UU tentang diperbolehkannya beroperasinya bank syariah di Indonesia. Selain itu juga jika kita dapat menjalin hubungan baik dengan pemerintah local karena ada kemungkinan dana dari 
instansi pemerintah tersebut dapat diinvestasikan di PT. Panin Bank Syariah, Tbk. Kantor Cabang Malang, dan jika ada proyek-proyek yang lain bisa berkemungkinan bekerjasama dengan PT. Panin Bank Syariah, Tbk. Kantor Cabang Malang karena hubungan antara nasabah dan bank adalah kemitraaan. Jalinan hubungan yang perlu ditingkatkan yang ketiga adalah dengan komunitas. Hal ini perlu ditingkatkan karena komunitas merupakan prospek nasabah potensial yang hendak dituju oleh PT. Panin Bank Syariah, Tbk. Kantor Cabang Malang. Jika hubungan ini bisa terjalin dengan baik maka diharapkan para komunitas yang ada bisa menjadi partner yang membantu terhadap perkembangan PT. Panin Bank Syariah, Tbk. Kantor Cabang Malang.

d. Menjalin kerjasama dengan lembaga pendidikan

Kota Malang disebut sebagai kota pelajar bukan tanpa alasan karena diwilayah kota malang saja ada 53 perguruan tinggi baik yang negeri maupun swasta. Sehingga bekerjasama dengan perguruan tinggi merupakan salah satu cara yang efektif untuk strategi pemasaran PT. Panin Bank Syariah, Tbk. Kantor Cabang Malang. Kebayakan perguruan tinggi tidak mau direpotkan oleh masalah administrasi keuangan karena jumlah mahasiswanya begitu banyak. Strategi ini bersal dari penggabungan kekuatan PT. Panin Bank Syariah, Tbk yang memiliki tempat strategis dengan peluang yang ada yaitu kota pelajar.

\section{Strategi WO (Weakness opportunities)}

Strategi WO ditetapkan pada faktor kelemahan dan peluang. Strategi WO yang bisa dilakukan adalah:

a. Strategi jemput bola

Strategi ini perlu terus dikembangkan dalam rangka mencari nasabah sebanyak mungkin. Hal ini dikarenakan banyak masyarakat yang belum banyak mengenal adanya PT. Panin Bank Syariah, Tbk. Kantor Cabang Malang. Apabila posisinya yang kurang strategis dan umurya yang bisa dibilang masih baru sehingga banyak masyarakat yang belum tau adanya PT. Panin Bank Syariah, Tbk di Malang. Strategi ini dilakukan dengan tujuan untuk mempertahankan posisi pasar yang ada dan menambah jumlah nasabah yang menjadi mitra PT. Panin Bank Syariah, Tbk.Strategi ini digunakan untuk memperkecil kelemahan tempat kurang menarik dengan menggunakan peluang pangsa pasar yang masih luas.

b. Meningkatkan loyalitas nasabah

Peran nasabah pembiayaan maupun nasabah investasi sangat berpengaruh terhadapkemajuan PT. Panin Bank Syariah, Tbk. Kantor Cabang Malang. Rasionalnya tidak ada nasabah maka tidak akan ada bank. PT. Panin Bank Syariah, Tbk. Kantor Cabang Malang perlu meningkatkan loyalitas nasabah dengan cara memupuk dan memelihara rasa kekeluargaan dan kepercayaan dengan memberikan pelayanan yang prima dan fasilitas yang memuaskan. Dengan keloyalitasan nasabah secara tidak langsung sudah ikut mempromosikan PT. Panin Bank Syariah, Tbk. Kantor Cabang Malang melalui mouth to mouth dan tidak diragukan mereka yang loyal akan mengajak orang sekitarnya untuk menggunakan jasa PT. Panin Bank Syariah, Tbk. Kantor Cabang Malang. Strategi ini digunakan untuk 
memperkecil kelemahan proses pencairan dan pembiayaan yang lama dengan memanfaatkan peluang manyoritas penduduk malang adalah muslim.

c. Peningkatan kualitas produk

Jasa atau Produk yang ditawarkan oleh PT. Panin Bank Syariah, Tbk. Kantor Cabang Malang hendaknya sesuai dengan kebutuhan dan keinginan nasabah. Sehingga produk pembiayaan yang ditawarkan bank kepada nasabah agar produk tersebut tetap mempunyai nilai jual kepada nasabah. Misalnya Mungkin dengan memberikan kemudahan atau kacepatan dalam memberikan pelayanan kepada para nasabah. Karena untuk saat ini untuk satu proses pengajuan pembiayaan normalnya memerlukan waktu sekitar 14 hari kerja.Strategi ini digunakan untuk memperkecil kelemahan proses pencairan dana pembiayaan yang lama dengan memanfaatkan peluang banyaknya bank syariah.

\section{Strategi ST (strenghts treaths)}

Strategi ST merupakan strategi yang berdasar pada faktor kekuatan dan ancaman. Strategi ini meliputi:

a. Menetapkan target pemasaran

Lembaga keuangan yang menjadi pesaing berat PT. Panin Bank Syariah, Tbk. Kantor Cabang Malang adalah bank konvensional dan bank syariah yang ada disekitar kota malang. Oleh sebab itu PT. Panin Bank Syariah, Tbk. Kantor Cabang Malang harus menetapkan pasar sasaran dan target-target pemasaran. Jangan sampai target pemasaran tersebut salah sasaran. PT. Panin Bank Syariah, Tbk. Kantor Cabang Malangharus melihat peluang-peluang yang terlewati oleh bankbank konvensional dan bank-bank syariah yang ada di sekitar kota malang. Target pemasaran itu tidak harus satu segmen saja, bisa juga lebih dari satu asalkan diperhitungkan dan rencanakan segmen apa yang sesuai dengan produk pembiayaan yang ditawarkan oleh PT. Panin Bank Syariah, Tbk. Kantor Cabang Malang. Strategi ini digunakan kekuatanya yaitu tempat yang strategis untuk menghilangkan atau memperkecil ancaman dari bank syariah lainnya.

\section{b. Meningkatkan kualitas pelayanan}

Peningkatan kualitas pelayanan harus terus ditingkatkan untuk menarik simpati nasabah maupun calon nasabah. Kalau bisa pelayanan yang diberikan oleh PT. Panin Bank Syariah, Tbk. Kantor Cabang Malang kepada nasabah mempunyai nilai lebih dibandingkan dengan pelayanan di bank konvensional dan bank syariah yang lain . Sehingga rasa kenyamanan nasabah terhadap bank makin meningkat, dan pada akhirnya loyalitas kepada nasabah juga meningkat. Karena keloyalitasan nasabah merupakan salah satu hal yang penting untuk menjaga kelangsungan hidup bank.Strategi ini digunakan kekuatanya yaitu jaringan kerja yang dimiliki untuk menghilangkan atau memperkecil ancaman dari masyarakat yang iri dan tidak tahu. c. Membuat produk yang inovatif

Banyaknya produk yang ditawarkan kepada nasabah bukan jaminan bila nasabah akan memilih PT. Panin Bank Syariah, Tbk. sebagai mitranya. Produk banyak tetapi tidak sesuai dengan kebutuhan atau keinginan nasabah maka tidak akan dipilih. Membuat produk yang inovatif merupakan salah satu solusi untuk menagatasinya, misalnya produk pembiayaan yang nominalnya kurang dari 
500.000.000 proses pencairannya maksimal satu minggu, sehingga nasabah puas dengan pelayanan yang diberikan. Strategi ini digunakan kekuatanya yaitu fleksibel untuk menghilangkan atau memperkecil ancaman dari Ekonomi ASEAN.

\section{Strategi WT (Weakness treaths)}

Strategi yang bersifat defensif untuk meminimalisasi kelemahan dan ancaman. Strategi ini terdiri dari:

a. Peningkatan promosi melalui berbagai media

Langkah-langkah selanjutnya yang tidak boleh ditinggalkan adalah promosi. Dalam rangka mensosialisasikan keberadaan PT. Panin Bank Syariah, Tbk. di Malang. Banyak media yang bisa dimanfaatkan baik media cetak maupun elektronik, ataupun bisa juga dilakukan melalui kontak secara langsung. Misalnya melalui komunitas-komunitas yang ada di Malang, pengajian dan acara-acara lain yang melibatkan masyarakat banyak. Karana masalah yang sangat penting untuk saat ini adalh ketidaktahuan masyarakat akan adanya PT. Panin Bank Syariah, Tbk. di Kota Malang. Untuk saat ini media elektronik yang paling murah dan efektif adalah media online karena saat ini hamper semua orang menggunakan media ini untuk berbagai keperluan dan setiap detiknya pasti ada orang yang melihat media online baik untuk hiburan maupun untuk pekerjaan.Strategi ini berusaha untuk menghilangkan kelemahan kurangnya sosialisasi dan produk yang tidak terkenal, serta untuk meminimalkan ancaman dari banyaknya bank syariah lainnya.

b. Menetapkan strategi pemasaran yang efektif dan efisien

PT. Panin Bank Syariah, Tbk. Kantor Cabang Malang hendaknya menetapkan strategi pemasaran yang efektif dan efisien dalam rangka menghindari ancaman dan memperkecil kelemahan. Maksudnya adalah dalam menetapkan strategi pemasaran disesuaikan dengan kekuatan dan peluang yang ada. Jangan sampai kekuatan dan peluang yang sudah dimiliki berubah menjadi ancaman bagi bank itu sendiri. Misalnya peluang-peluang yang ada tidak digunakan semaksimal mungkin sehingga peluang tersebut digunakan oleh bank atau lembaga keuangan yang lain. Strategi ini berusaha untuk menghilangkan kelemahan proses pencairan dana pembiayaan yang lama dan meminimalkan ancaman atas ketidak mapuan menggunakan kekuatan dan peluang yang ada serta persiapan untuk menghadapi dampak dari Ekonomi ASEAN.

\section{Strategi Pemasaran berdasar Matriks SWOT PT. Panin Bank Syariah, Tbk. Kantor Cabang Malang}

Dari hasil matriks SWOT dapat diambil beberapa strategi yang sesuai dengan keadaan PT Panin Bank Syariah, Tbk. Kantor Cabang Malang bedasarkan beberapa hal yaitu :

\section{Segmentasi}

Berdasarkan tahapan dalam menentukan strategi pemasaran segmentasi merupakan tahapan pertama. Dari hasil analisis SWOT yang dilakuakan Segmentasi yang sesuai dengan keadaan bank adalah segmentasi Koperasi. Hal ini dikarenakan Bank atau lembaga keuangan yang pangsa pasarnya koperasi masih sedikit, yakni BTN, BMI dan NIAGA. 
2. Targeting

Dalam hal penentuan posisi pasar PT Panin Bank Syariah, Tbk. Kantor Cabang Malang ada lima alternative yang dapat diambil yaitu:

a. Konsentrasi pada pasar tunggal yaitu koperasi.

b. Spesialisasi Efektif yaitu spesialisasi pada beberapa segmen sesuai dengan SDM yang dimiliki.

c. Spesialisasi Pasar dalam hal ini bank mengkhususkan diri untuk melayani kebutuhan sekelompok tertentu saja yang sesuai saat ini adalah pasar koperasi dan korporat.

d. Spesialisasi Produk dalam hal ini bank hanya memfokuskan kapada produk tertentu misalnya Permbiayaan Modal Kerja yang sesuai dengan segmentasi pasar koperasi.

e. Pasar Secara Menyeluruh yaitu melayani semua segmen yang ada baik Korporat, Koperasi maupun Individu.

\section{Positioning}

Dalam menentukan posisi pasar bank harus menempatkan produk yang sesuai dengan posisi segmentasi pasar dan menetapkan bauran pemasaran secara terperinci. Sehingga nasabah dapat membedakan produk pembiayaan di PT. Panin Bank Syariah, Tbk dengan produk pembiayaan pesaing. Misalnya salah satu ada produk yang dikhususkan untuk para pensiunan. Sehingga bila ada nasabah yang jaminanya adalah tunjangan pensiun, maka bank yang akan dituju untuk mengajukan pembiayaan adalah PT. Panin Bank Syariah, Tbk.

\section{Bauran Pemasaran}

Dalam menentukan strategi pemasaran bauran pemasaran dibagi menjadi tujuh yaitu :

a. Produk

Dalam hal ini bank harus membuat produk yang lebih inovatif dan sesuai kebutuhan nasabah, misalnya untuk pembiayaan yang nominalnya dibawah 500.000.000 hanya memerlukan waktu satu minggu, karena biasanya nominal tersebut untuk oramg orang yang memerlukan pembiayaan yang mendesak dan dibutuhkan cepat.

b. Price ( Harga)

Penentuan \% margin dengan nasabah harus memperhatiakan beberapa hal yaitu Kebutuhan Dana, Persaingan, Kebijakan Pemerintah, Target Laba yng Diinginkan, Jangka Waktu, Kualitas Jaminan, Reputasi Perusahaan, Produk yang Kompetitif, Hubungan Baik, Jaminan Pihak Ketiga. Sehingga PT. Panin Bank Syariah, Tbk dapat bersaing secara kompetitif dengan para pesaingnya.

c. Place ( Tempat)

Karena untuk saat ini tempat yang digunakan PT. Panin Bank Syariah, Tbk Kantor Cabang Malang sudah strategis, maka tinggal bangunannya saja yang perlu diperbaiki. Karena secara langsung dapat mempengaruhi minat nasabah yang ingin bergabung dengan PT. Panin Bank Syariah, Tbk. Untuk saat ini gedung yang digunakan perlu direnovasi ulang karena sudah termasuk dalam bangunan tua. Sehingga nasabah beranggapan bahwa gedung tersebut kantor yang tidak digunakan lagi. 


\section{d. Promotion ( Promosi )}

Seperti hasil dari matriks SWOT langkah-langkah selanjutnya yang tidak boleh ditinggalkan adalah promosi. Dalam rangka mensosialisasikan keberadaan PT. Panin Bank Syariah, Tbk. di Malang. Banyak media yang bisa dimanfaatkan baik media cetak maupun elektronik, ataupun bisa juga dilakukan melalui kontak secara langsung. Misalnya melalui komunitaskomunitas yang ada di Malang, pengajian dan acara-acara lain yang melibatkan masyarakat banyak.

e. People ( Orang)

PT. Panin Bank Syariah, Tbk hendaknya dalam merekut karyawan tidak hanya melihat dari penampilan fisiknya saja, tetapi juga skill, sikap, komitmen dan kemampuannya. Karena para karyawan ini secara langsung akan behadapan dengan para nasabah dan hal ini dapat mempengaruhi persepsi nasabah. Percuma bila memiliki karyawan yang hanya baik penampilanya saja akan tetapi tidak memiliki kemampuan menghadapi nasabah yang memiliki berbagai macam karater.

f. Process ( Proses )

Untuk saat ini proses pencairan dana di PT. Panin Bank Syariah, Tbk Kantor Cabang Malang lumanyan lama yaitu memerlukan sekitar 14 hari kerja bila semua persyaratan sudah dipenuhi. Hal ini dikarenakan PT. Panin Bank Syariah, Tbk Kantor Cabang Malang belum memiliki tim appraisal sendiri masih memakai tim dari cabang Surabaya. Bila memungkinkan kantor Cabang Malang memiliki tim appraisal sendiri sehingga operasional dalam proses pencairan dana pembiayaan tidak terlalu lama.

\section{g. Physical Evidence (Bukti Fisik )}

Dalam hal ini adalah sarana dan prasarana yang dapat dilihat secara fisiknya. Untuk saat ini sarana dan prasarana masih belum mamadai perlu adanya penambahan mobil dinas karena mobil dinas yang hanya dua dirasa kurang, bila dibandingkan dengan jumlah marketingnya delapan orang, guna untuk memperlancar jika berhubungan dengan nasabah.

\section{KESIMPULAN}

\section{Kesimpulan}

Berdasarkan penelitian yang telah dilakukan oleh peneliti, maka ada beberapa kesimpulan yang bisa diambil dari hasil penelitian ini yaitu:

a. Strategi pemasaran khususnya pemasaran produk pembiayaan yangditerapkan oleh PT. Panin Bank Syariah, Tbk. Kantor Cabang Malang meliputi beberapa strategi, yakni strategi jemput bola, referal, membangun jaringan, memberikan servise excellent, dan memberikan fasilitas yang memuaskan untuk meningkatkan kepercayaan dan kepuasan nasabah, sehingga nasabah yang ada tidak akan lari dari bank.

b. Hasil analisis SWOT menyebutkan bahwa PT. Panin Bank Syariah, Tbk. Kantor Cabang Malangsudah bisa bersaing di pasar persaingan yang kompetitif yang ada di wilayah Malang. Hasil analisis SWOT nya pun hampir memiliki kesamaan dengan bank syariah pada umumnya. Berdasarkan interpretasi 
analisis SWOT, pengembangan strategi pemasaran produk pembiayaan yang bisa dilakukan oleh PT. Panin Bank Syariah, Tbk. Kantor Cabang Malangadalah dengan memanfaatkan kekuatan dan peluang yang ada, serta meminimalkan kelemahan dan ancaman. Strategi pemasaran pembiayaan yang bisa ditempuh oleh PT. Panin Bank Syariah, Tbk. Kantor Cabang Malangterdiri dari :

a. Strategi SO (strenght opportunities)

Meliputi pangsa pasar, memperkuat kerjasama dengan koperasi, meningkatkan hubungan dengan ulama, pemerintah, dan komunitas, serta menjalin kerjasama dengan lembaga pendidikan.

b. Strategi WO (Weakness oppotunities)

Yakni melakukan strategi jemput bola, meningkatkan loyalitas nasabah, dan peningkatan kualitas produk.

c. Strategi ST (strenght treaths)

Menetapkan target pemasaran, meningkatkan kualitas pelayanan dan membuat produk yang inovatif .

d. Strategi WT (Weakness treaths)

Yaitu pelaksanaan peningkatan promosi melalui berbagai media dan menetapkan strategi pemasaran yang efektif dan efisien.

\section{Saran}

Saran-saran yang diberikan peneliti dalam penelitian ini khususnya bagi PT. Panin Bank Syariah, Tbk. Kantor Cabang Malangadalah sebagai berikut:

1. Dalam menentukan strategi pemasaran, PT. Panin Bank Syariah, Tbk. Kantor Cabang Malang harus memanfaatkan kekuatan dan peluang yang dimiliki dengan tetap memandang faktor kelemahan dan ancaman. Jangan sampai kekuatan dan peluang berubah menjadi ancaman besar bagi bank sendiri.

2. Untuk menarik masyarakat agar menjadi nasabah, maka sosialisasi dan promosi harus selalu dilakukan baik secara tertulis maupun secara langsung, selain itu PT. Panin Bank Syariah, Tbk. Kantor Cabang Malangjuga harus tetap meningkatkan pelayanan kepada nasabah, melengkapi fasilitas agar lebih memadai.

3. Jaringan merupakan salah satu hal yang sangat berpengaruh terhadap kemajuan bank, oleh karena itu hendaknya PT. Panin Bank Syariah, Tbk. Kantor Cabang Malanglebih meningkatkan hubungan dengan pihak-pihak terkait yang bermanfaat bagi kemajuan dan perkembangan bank.

4. Produk pembiayaan yang ditawarkan hendaknya memiliki keunggulan yang tidak dimiliki oleh lembaga keuangan lain dari segi kualitas.

5. Agar dapat bersaing di pasar persaingan yang semakin sengit dan kompetitif ini, hendaknya PT. Panin Bank Syariah, Tbk. Kantor Cabang Malang mampu memanfaatkan peluang-peluang yang ada dan selalu melakukan inovasiinovasi produk supaya mempunyai nilai jual tinggi dan diminati oleh para calon nasabah. 


\section{DAFTAR PUSTAKA}

Arifin, Zainul. 2002. Dasar-Dasar Manajemen Bank Syariah, Jakarta, AlvaBet

Burhanuddin. 2010. Aspek Hukum Lembaga Keuangan Syariah, Yogyakarta, Graha Ilmu

Choirunnisak. 2012. Penerapan Analisis Swot Dalam Strategi Pemasaran Produk Tabungan, Tugas Akhir, Sekolah Tinggi Agama Islam Negeri (STAIN) Salatiga, Salatiga

Cravens, David W. 1996. Pemasaran Strategi edisi ke-4, Jilid 2, Jakarta, Erlangga

Efferin, Sujoko, et al, 2008. Metode Penelitian Akuntansi, Edisi I, Graha Ilmu, Yogyakarta

Fahmi, Irham. 2013. Manajemen Risiko Teori, Kasus dan Solusi, Bandung, Alfabeta

http://www.kopsyahirsyady.com/perbankan/572-babak-baru-panin-bank-syariah. Diakses pada tanggal 10 april 2014 pada jam 18.30

http://www.bi.go.id. Diakses pada tanggal 9 mai 2014 pada jam 18.45

Kasmir. 2004. Pemasaran Bank, Jakarta, Perenada Media

Kotler, Philip. 1997. Manajemen Pemasaran Analisis Perencanaan, Implementasi dan Pengendalian, terjemahan Jaka Wasana, Jakarta, Salemba Empat

Kotler, Philip dan Kevin Lane Keller. 2009. Manajemen Pemasaran, terjemahan Bob Sabran, Edisi 13, Jakarta, Erlangga

Nuariputri, Hanna. 2010. Analisis Swot Terhadap Penetapan Strategi Pemasaran, Tugas Akhir, Universitas Sebelas Maret Surakarta, Solo

Rangkuti, Fredy. 2005. Analisa SWOT Teknik Membedah Kasus Bisnis, Cetakan keduabelas, Jakarta, Gramedia Pustaka Utama

Ratih Hurriyati, 2005, Bauran Pemasaran dan Loyalitas Konsumen, Bandung: Alfabeta

Rianto,Nur. 2010. Dasar-Dasar Pemasaran Bank Syariah. Bandung, Alfabeta

Simamora,Bilson. 2004. Memenangkan Pasar dengan Pemasaran Efektif dan Profitabel, Jakarta, PT. Gramedia Pustaka Utama

Sinungan, Muchdarsyah .2000. Manajemen Dana Bank, Jakarta, Bumi Aksara 
Sriwahyuni, Agustinus. 1996. Manajemen Strategik Pengantar Proses Berfikir Strategik, Jakarta, Binarupa Aksara

Sucipto,Agus. 2011. Studi Kelayakan Bisnis, Cetakan II, Malang, UIN-Maliki Press

Sugyono. 2012. Memahami Penelitian Kualitatif. Bandung, CV Alfabeta

Swastha, Basu dan Irawan. 2005. Manajemen Pemasaran Modern, Yogyakarta, Liberty

Warsono, Sony dan Jufri, 2011. Akuntansi Transaksi Syariah, Asgard Chapter, Jakarta

Wirdyaningsih. 2005. Bank dan Asuransi Islam Di Indonesia, Jakarta, Kencana

www.malangkota.go.id. Diakses pada tanggal 4 Juni 2014 pada jam 10.15

www.sp2010.bps.go.id. Diakses pada tanggal 4 Juni 2014 pada jam 10.25 